\title{
Denervation (ablation) of nerve terminalis in renal arteries: early results of interventional treatment of arterial hypertension in Poland
}

\author{
Krzysztof Bartuś ${ }^{1}$, Jerzy Sadowski ${ }^{1}$, Bogusław Kapelak ${ }^{1}$, Wojciech Zajdel², Jacek Godlewski ${ }^{2}$, \\ Stanisław Bartuś ${ }^{3}$, Maciej Bochenek ${ }^{1}$, Magdalena Bartuś ${ }^{4}$, Krzysztof Żmudka², Paul. A. Sobotka ${ }^{5}$ \\ 'Department of Cardiovascular Surgery and Transplantology, Jagiellonian University, John Paul II Hospital, Krakow, Poland \\ 2John Paul II Hospital, Krakow, Poland \\ ${ }^{3}$ University Hospital in Krakow, Poland \\ ${ }^{4}$ Department of Experimental Pharmacology, Jagiellonian University, Krakow, Poland \\ ${ }^{5}$ The Ohio State University, Columbus, OH, USA; Medtronic Inc., Santa Rosa, CA, USA
}

\begin{abstract}
A b s tract
Background: Arterial hypertension is one of the main causes of cardiovascular disease morbidity and overall mortality.

Aim: To report the single centre experiences with changes in arterial blood pressure (BP) in patients after intra-arterial application of radiofrequency (RF) energy to cause renal sympathetic efferent and somatic afferent nerve and report vascular and kidney safety in a six month follow up.

Methods: Twenty-eight patients, with hypertension despite medical therapy (median age 52.02 years, range 42-72 years) consented to therapeutic renal nerve ablation. SIMPLICITY RF catheters and generator provided by Ardian (currently Medtronic Inc., USA) were used to perform renal artery angiography and ablation.

Results: The mean BP at baseline, and after one month, three months and six months were measured [mm Hg]: systolic 176.6; $162.3(p=0.004) ; 150.6(p<0.001) ; 147.2(p<0.001)$; diastolic 100.2; $90.3(p<0.001) ; 91.79(p=0.03)$; 88.5 ( $p<0.001)$; pulse pressure 76.57; $75.18(p=N S) ; 65.80(p<0.001) ; 62.15(p<0.001)$. Neither procedure-related nor therapy-related complications were reported in the six month follow up.

Conclusions: In our cohort of patients, intra-arterial renal nerve denervation was not associated with either vascular or renal complications out to six months. Nerve ablation of renal arteries led to significant reduction of mean values of arterial systolic, diastolic BP and significant reduction of pulse pressure. The Polish experience is not significantly different compared to that reported in the Symplicity I and Symplicity II international cohorts. The long term durability of this therapy and its application to earlier stages of hypertension or other disease states will require further investigation.
\end{abstract}

Key words: arterial hypertension, renal related hypertension, resistant hypertension, renal arteries ablation

Kardiol Pol 2013; 71, 2: 152-158

\section{INTRODUCTION}

Arterial hypertension is one of the main causes of cardiovascular disease morbidity and overall mortality, including cerebral, cardiac, renal and peripheral vascular diseases. Despite the broad availability of numerous classes of hypotensive medications, half of all hypertensive patients never achieve the recommended levels of blood pressure (BP) [1, 2]. Patient non-compliance with diet, exercise and medical therapy is often cited as a significant contribution to this failure. However, therapeutic inertia and possible adverse events related to lifelong poly pharmacy are also likely. Regardless of the cause of therapeutic failure, hypertensive patients remain at excess

\footnotetext{
Address for correspondence:

Krzysztof Bartuś, MD, PhD, Department of Cardiovascular Surgery and Transplantology, Jagiellonian University, John Paul II Hospital, ul. Prądnicka 80,

31-202 Kraków, Poland, tel: +48 1261430 75, fax: +48 1242339 00, e-mail:cool_chris@interia.pl

Received: 02.05.2012 Accepted: 07.11.2012

Copyright (C) Polskie Towarzystwo Kardiologiczne
} 
risk of renal failure, stroke or myocardial infarction (MI), and it remains a vital healthcare priority to identify alternative and successful treatment options for these patients.

Selectively disabling the renal sympathetic fibres (RD, renal denervation) using a straightforward intra-arterial approach offers significant potential to improve BP management in pharmaceutical-resistant patients, as well as offering a therapeutic option for patients who choose not to be, or cannot be, compliant with a lifelong poly pharmacy strategy for BP control. The concept of sympathetic denervation is not new since radical sympathectomy has been applied in patients with resistant malignant hypertension. However, the new availability of a simple approach and selective renal nerve ablation offer the potential advantages of the surgical approach without the surgical morbidity and complications associated with non-selective sympathetic denervation [3].

A recently introduced method of percutaneous catheter-based intraluminal selective sympathetic nerve ablation of renal arteries using radiofrequency (RF) current is gaining more attention. Initial studies using this method have shown [4-6] effective reduction of sympathicomimetic activity and renin secretion as well as an acceptable safety profile and significant reduction in BP levels without major adverse outcomes.

The aim of this study was to assess changes in arterial BP levels in patients after ablation of nerve terminalis in renal arteries (denervation) as well as procedure safety in a six month follow up.

\section{METHODS}

The primary enrollment criterion was the presence of resistant arterial hypertension, defined as mean brachial artery seated systolic pressure above $160 \mathrm{~mm}$ Hg during out-patient department visits, despite historical compliance with at least three antihypertensive drugs (including a diuretic) in optimal doses. Other enrollment criteria are listed in Table 1. BP measurement was always performed with an automatic device with a printer — OMRON 7051T, by the same person after ten minutes of rest, three times at five-minute intervals. In order to qualify each patient for the invasive procedure and assess the effect of the procedure, a mean value of three measurements was taken into consideration. Patients with renal failure and renal artery disease or with anatomic contraindications to safe ablation (renal artery lumen diameter $<4 \mathrm{~mm}$, double or narrow renal arteries, critical stenosis) were excluded (see Table 1 for exclusion criteria). Four weeks before the invasive procedure, the mean values of $\mathrm{BP}$ in all subjects were stable and pharmacological treatment remained unchanged. No changes in pharmacotherapy were recommended in the follow up period after the procedure.

Twenty-eight patients (median age 52.02 years, range 42-72 years) with diagnosed arterial hypertension resistant to pharmacological treatment were identified and consented to therapeutic RD and the follow up procedures. Baseline characteristics are presented in Table 2.
Table 1. Inclusion and exclusion criteria

\section{Inclusion criteria}

1. Patients over 18 years with systolic blood pressure over $160 \mathrm{~mm} \mathrm{Hg}$

2. Patients receiving full doses of three antihypertensive drugs (including a diuretic) for at least two weeks before enrollment

3. Estimated glomerular filtration rate over $45 \mathrm{~mL} / \mathrm{min}$

4. Written consent

Exclusion criteria

1. Renal arteries anomalies:

a. Haemodynamically significant renal artery stenosis (over $50 \%$ ) by visual assessment

b. Atherosclerotic lesion or stenosis within the artery which may potentially, according to the operator, add additional hazard to patient safety during artery catheterisation

c. Haemodynamically or physiologically significant stenosis which may be responsible for arterial hypertension

d. Prior renal artery stenting or angioplasty

e. Patients with more than one renal artery at one side

2. Suspicion of secondary hypertension or diagnosed secondary hypertension regardless of the underlying cause (including one associated with administered drugs)

3. Patients with history of coronary artery disease manifested by myocardial infarction, unstable angina or stroke in the previous six months

4. Patients with significant valvular disease

5. Type 1 diabetes

6. Patients with implantable cardioverter-defibrillator or pacemaker

7. Patients requiring breathing support

8. Patients suffering from a disease or taking drugs which may potentially influence the effectiveness of the therapy (e.g. peripheral atherosclerosis, aortic aneurysm, bleeding disorders, thrombocytopenia, anaemia, arrhythmia, alcohol abuse, drug addiction)

9. Patients who plan pregnancy or are pregnant

Height ranged from 147 to $184 \mathrm{~cm}$ (mean value $167.8 \mathrm{~cm}$ ); weight ranged from 60 to $122 \mathrm{~kg}$ (mean value $89.5 \mathrm{~kg}$ ). The co-existing comorbidities included: hypercholesterolaemia was diagnosed in 20 patients, diabetes mellitus type 2 in seven, and peptic ulcer disease in three. Nine patients had prior symptoms of coronary artery disease, of whom one had suffered from MI and had had percutaneous coronary intervention with stent implantation; another had had prior coronary artery bypass surgery. One patient had mild aortic valve stenosis, and one had asthma and chronic obstructive pulmonary disease. Only two patients were diagnosed with chronic renal insufficiency according to elevated creatinine and urea in blood serum. No patient had symptoms of peripheral artery disease. The NYHA scale was 1.8 for this cohort of patients (range 1 to 3 ). The mean value of three measurements of BP before ablation was: systolic from 160 to $212 \mathrm{~mm} \mathrm{Hg}$ (mean value $176.6 \mathrm{~mm} \mathrm{Hg}$ ), diastolic 
Table 2. Baseline characteristics

\begin{tabular}{|lc|}
\hline Patient numbers (men, women) & 28 (16 male, 12 female) \\
Age (mean) [years] & $42-72(52.02)$ \\
Height (mean) [cm] & $147-184(167.8)$ \\
Weight (mean) $[\mathrm{kg}]$ & $60-122(89.5)$ \\
Abdominal obesity (waist & $6(21 \%)$ \\
circumference $>102 \mathrm{~cm}$ in men, & \\
$88>$ cm in women) & $20(71 \%)$ \\
Hypercholesterolaemia & $2(7 \%)$ \\
Current smoking (number of patients) & $1(3 \%)$ \\
Impaired glucose tolerance & $7(25 \%)$ \\
Diabetes mellitus type II & $9(32 \%)$ \\
Coronary artery disease & $3(10 \%)$ \\
Peptic ulcer & $1(3 \%)$ \\
Aortic stenosis & $1(3 \%)$ \\
Asthma, chronic obstructive pulmo- & \\
nary disease & 1.8 \\
Creatinine [ $[$ mmol/L] & 0 \\
Heart failure (mean), NYHA grade & 0 \\
Advanced retinopathy & 0 \\
Intermittent claudication & $53.0-123.0(\mathrm{mean} 85.6)$ \\
Stroke &
\end{tabular}

from 84 to $121 \mathrm{~mm} \mathrm{Hg}$ (mean value $100.28 \mathrm{~mm} \mathrm{Hg}$ ). The heart rate ranged from 60 to $98 / \mathrm{min}$ (mean value $73.4 / \mathrm{min}$ ).

The procedure was performed in the usual manner. SIMPLICITY catheters and generators were delivered by the Ardian company (currently Medtronic Inc., USA). All procedures were performed via femoral artery following administration of unfractionated heparin $(100 \mathrm{U} / \mathrm{kg})$, a standard for renal artery angiography. There were up to six two-minute pre-programmed applications of RF energy treatments in each renal artery, with a maximum $8 \mathrm{~W}$ energy.

The six ablations were performed in a helical pattern, separated by $5 \mathrm{~mm}$. The temperature at the tip of the catheter was monitored by the ablation system as well as tissue resistance to guide therapeutic and safe application of energy by a provided and programmed generator algorithm. After the procedure, patients were followed up in visits at one, three and six months. BP measurements were performed (according to the methodology described earlier), blood count, electrolytes, urea, creatinine and urine were evaluated at each visit, as well as physical exam including orthostatic BP measures.

Patients were monitored for major adverse cardiac events such as death, stroke, $\mathrm{MI}$ or outcomes associated with the procedure itself, such as retroperitoneal bleeding, renal artery stenosis, and access site complications.

This paper is a subanalysis of the patients recruited to the SIMPLICITY study published in the Lancet in 2009 [4].
The study was approved by the Bioethics Committee at the Jagiellonian University in Krakow, Poland.

\section{Statistical analysis}

For statistical analysis, we assessed continuous variables between groups, including the primary endpoint, with Student's two-sample t test. We compared categorical variables with Fisher's exact test; for within group paired data, a paired $t$ test was used. Two-sided alpha level of 0.05 was used for all superiority testing. All statistical analyses were done with SAS version 9.2.

\section{RESULTS \\ Periprocedural}

There were no access site complications or significant vascular, renal or cardiovascular adverse events reported. During the procedure, many patients reported epigastric diffuse pain predictably starting after each ablation and ending promptly with the end of therapy. Pre procedure sedatives and amnesics were used in all patients and supplemental intravenous opioids were used in most.

All 28 patients were discharged home $2-5$ days after the procedure (mean stay was 3.1 days). The hospitalisation length was unrelated to the procedure.

\section{One month after the procedure}

Twenty-one patients were seen by protocol one month after the procedure. Their weight ranged from 72 to $120 \mathrm{~kg}$ (mean value $89.22 \mathrm{~kg}$ ) and was not statistically different from baseline before the procedure. In this cohort of patients, the mean value of BP was: systolic from 135 to $185 \mathrm{~mm} \mathrm{Hg}$ (mean value $162.3 \mathrm{~mm} \mathrm{Hg}$ ), and diastolic from 77 to $103 \mathrm{~mm} \mathrm{Hg}$ (mean value $90.3 \mathrm{~mm} \mathrm{Hg}$ ); this was a mean reduction of $14.3 \mathrm{~mm} \mathrm{Hg}$ in systolic and $10.02 \mathrm{~mm} \mathrm{Hg}$ in diastolic BP compared to baseline values. These changes were statistically significant. The mean pulse pressure was $75.18 \mathrm{~mm} \mathrm{Hg}$. Of the 21 patients, six (28\%) had more than a $10 \mathrm{~mm} \mathrm{Hg}$ fall in systolic BP (Table 3, Fig. 1).

The mean values of heart rate ranged from 60 to $80 / \mathrm{min}$ (mean value $72 / \mathrm{min}$ ) during the one month check-up visit. The mean heart rate was $0.6 \mathrm{bpm}$ lower than the baseline heart rate value, although this was not statistically significant.

No crucial changes in pharmacotherapy or dosages of drugs were noted, nor any complications related to the procedure. One patient reported chest pain in the month following the procedure, but neither non-invasive tests nor subsequent coronary angiography revealed significant coronary artery disease or recent MI. The pain was adjudicated as unrelated to the procedure.

Urine sample tests were within standards. Baseline blood parameters did not reveal a rise in renal parameters used to detect for renal failure. 
Table 3. Blood pressure changes, weight and heart rhythm changes

\begin{tabular}{lcccc} 
& Baseline & 1 month & 3 months & $\mathbf{6}$ months \\
\hline $\mathrm{N}$ & 28 & 21 & 26 & 26 \\
$\begin{array}{l}\text { Systolic blood pressure } \\
\text { (mean, median) }[\mathrm{mm} \mathrm{Hg}]\end{array}$ & $160-212(176.6,175)$ & $135-162.3(162.3,170)$ & $120-230(150.69,150)$ & $120-190(147.2,146,5)$ \\
$\begin{array}{l}\text { Diastolic blood pressure } \\
\text { (mean, median) }[\mathrm{mm} \mathrm{Hg}]\end{array}$ & $84-121(100.28,98.5)$ & $77-103(90.3,92)$ & $70-120(91.79,92)$ & $70-115(88.5,90)$ \\
$\begin{array}{l}\text { Pulse pressure } \\
\text { (mean) }[\mathrm{mm} \mathrm{Hg}]\end{array}$ & $56-100(76.57)$ & $52-93(75.18)$ & $36-118(65.80)$ & $35-90(62.15)$ \\
$\begin{array}{l}\text { Heart rhythm (mean) }[\mathrm{bpm}] \\
\text { Weight (mean) }[\mathrm{kg}]\end{array}$ & $60-98(73.4)$ & $60-80(72)$ & $52-100(74.39)$ & $56-104(71.96)$ \\
\hline
\end{tabular}

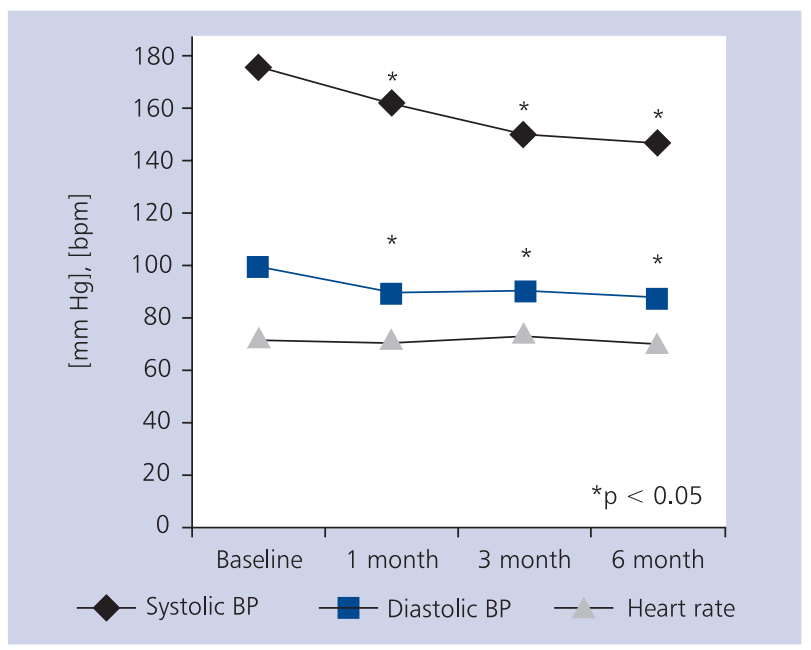

Figure 1. Mean systolic, diastolic blood pressure (BP) and heart rate at baseline and 1, 3 and 6 months after the procedure

\section{Three months after the procedure}

Three months after the procedure, 27 patients who had ablation performed were followed up. One patient stopped taking all prescribed medications and was excluded from the three-month analysis. All other patients remained on baseline pharmacotherapy, except for a single patient who had nitrendipine eliminated due to low BP.

The mean value of systolic BP for the remaining 26 patients ranged from 120 to $230 \mathrm{~mm} \mathrm{Hg}$ (mean value $150.69 \mathrm{~mm}$ $\mathrm{Hg}$ ) and was $26 \mathrm{~mm} \mathrm{Hg}$ lower than baseline (Table 3, Fig. 1). The mean value of diastolic BP for the remaining 26 patients ranged from 70 to $120 \mathrm{~mm} \mathrm{Hg}$ (mean value $91.79 \mathrm{~mm} \mathrm{Hg}$ ) and was $8.52 \mathrm{~mm} \mathrm{Hg}$ lower than baseline.

The mean pulse pressure decreased to $65.86 \mathrm{~mm} \mathrm{Hg}$. The mean values of heart rate ranged from 52 to 100/min (mean value $74.39 / \mathrm{min}$ ) during the three-month check-up visit. The mean heart rate did not differ from baseline and was statistically not significant.

No complications related to the ablation procedure nor adverse events were noted.
Urine sample tests were within standards. Baseline blood parameters did not reveal a rise in renal parameters used to detect for renal failure. The weight ranged from 71 to $105 \mathrm{~kg}$ (mean value $90 \mathrm{~kg}$ ) and was not statistically different from baseline before the procedure.

\section{Six months after the procedure}

Six months after the procedure, 26 patients were seen in follow up. All patients remained compliant with baseline pharmacotherapy.

The mean value of systolic BP for the 26 patients ranged from 120 to $190 \mathrm{~mm} \mathrm{Hg}$ (mean value $147.2 \mathrm{~mm} \mathrm{Hg}$ ) and was $29.4 \mathrm{~mm} \mathrm{Hg}$ lower than baseline (Table 3, Fig. 1). The mean value of diastolic BP for the 26 patients ranged from 70 to $115 \mathrm{~mm} \mathrm{Hg}$ (mean value $88.5 \mathrm{~mm} \mathrm{Hg}$ ) and was $11.78 \mathrm{~mm} \mathrm{Hg}$ lower than baseline before the ablation procedure. The pulse pressure decreased to $62.15 \mathrm{~mm} \mathrm{Hg}$ (mean value) from baseline 76.57 mm Hg (Table 3). Systolic, diastolic BP and pulse pressure were statistically significantly lower than at baseline.

The mean values of hoart rate ranged from 56 to 104/min (mean value $71.96 / \mathrm{min}$ ) during the six-month follow up. The mean heart rate was $1.44 \mathrm{bpm}$ lower than that measured before the procedure (statistically not significant).

No complications related to the ablation procedure nor adverse events were noted.

Urine samples tested six months after the procedure were within standards. Baseline blood parameters did not reveal a rise in renal parameters used to detect for renal failure. The weight six months after the procedure ranged from 60 to $126 \mathrm{~kg}$ (mean value $90.3 \mathrm{~kg}$ ) and was not statistically different from the mean value before the procedure.

\section{DISCUSSION}

The results of our study are in line with previously published data [4, 5], which have shown statistically significant BP reduction after renal artery denervation with RF current in patients with arterial hypertension resistant to pharmacotherapy.

The significant reduction in BP was confirmed during out-patient visits after standardised measurements in pa- 
tients receiving stable antihypertensive pharmacotherapy. In our study, RD led to $29.4 \mathrm{~mm} \mathrm{Hg}$ decrease in systolic and $11.78 \mathrm{~mm} \mathrm{Hg}$ decrease in diastolic BP, which was significant compared to baseline value (Fig. 1). This reduction of systolic and diastolic BP corresponds to a significant reduction of pulse pressure of $14.42 \mathrm{~mm} \mathrm{Hg}(\mathrm{p}<0.001)$. No adverse outcomes, complications such as renal failure, or clinically relevant renal artery stenosis occurred during follow up.

This Polish report is comparable to the international randomised clinical trial [6]. RD turned out to be a treatment method with sustainable BP decrease in patients with resistant hypertension. After a two-year follow up, observation of 153 patients in whom baseline BP was $176 / 98 \pm 17 / 15 \mathrm{~mm} \mathrm{Hg}$, a mean decrease of 32/14 mm Hg, was achieved which was statistically significant.

Among patients from the Simplicity I and Simplicity II trials assessed together, $84 \%$ of patients had durable lowering of BP (mean decrease in systolic BP was $32 \mathrm{~mm} \mathrm{Hg}$, and for the diastolic BP $12 \mathrm{~mm} \mathrm{Hg}$ after six months; $\mathrm{p}<0.001$ ) [7].

There is a cardiovascular mortality and cardiovascular morbidity benefit from a successful BP lowering therapy (systolic, diastolic and pulse pressure) [8-12]. The effect on all-cause mortality is less pronounced, while the reduction of mortality is principally related to a reduction of cerebrovascular events. Meta analysis supports a $2 \%$ reduction of mortality for every $1 \mathrm{~mm} \mathrm{Hg}$ reduction of systolic BP. The obvious BP lowering, especially the pulse pressure, certainly reflects future risk benefit for these patients, however, it is as yet too early to estimate the overall outcome of adverse events such as death, stroke and MI in long term observation in this smaller series. Nonetheless, the patients enrolled had exhausted alternative therapy, and RD has provided a calculable benefit in this cohort.

None of the current reports identify serious adverse events of the procedure, while several note transient bradycardia pseudoaneurysms in access site, rapid onset hypotonia, urinary tract infections, parestesia and pain, all self limited complications. Out of 206 patients who had denervation performed in the analysis of published studies, only five had complications in the form of pseudoaneurysms and dissection of renal artery caused by the ablation catheter [12].

To date, no long term vascular or renal complications have been identified [13]. The ablation itself is sterile, and preclinical trials show healed non-inflammatory lesions with mature fibrosis at the ablation sites, suggesting that there is little risk of late vascular complications. There is a theoretical potential for efferent sympathetic fibres to regrow, but it is generally felt that afferent fibres cannot. The recent report of sustained BP reduction out to three years (ACC 2012) confirms the durability of the procedure [14].

The benefits of RD may not be confined to the reduction of BP. Metabolic effect in hypertensive patients and associated with improvement of glucose tolerance and sleep apnoea was confirmed by Witkowski et al. [15] and in a study of RD in pa- tients with polycystic ovary syndrome [16]. The improvement on glucose tolerance was not associated with current therapy with insulin or oral drugs which has also been confirmed in other studies [17]. In our study, however, no observation focused on glucose tolerance was undertaken.

The potential of RD for patients who are persistently non-compliant, or who have proved intolerant to medications, has not been explored and the value of the therapy in patients with secondary hypertension, such as aldosteronism, remains to be investigated. Also, the value of this therapy in earlier non-resistant hypertension remains unexplored.

The role of sympathetic efferent and afferent somatic fibres in hypertension has long been proved in animal models, where efferent signals increase renin release, cause a rightward shift of the pressure natriuresis curve, and reduce renal bloodflow. Interfering with the deleterious effects of these signals may explain much of the underlying mechanism of $\mathrm{BP}$ reduction seen in this trial. Moreover, the potential of the kidney to modify the central sympathetic state via signals from its resident afferent somatic chemo and mechanoreceptors is intriguing. The reduction of total body noradrenaline and muscle sympathetic nerve activity supports this novel hypothesis [4, 6, 18].

If true, then the selective reduction of renal signalling to the hypothalamus may have value in the treatment of other disorders related to sympathetic hyperactivity, such as heart failure with preserved or reduced ejection fraction, hypertrophic heart disease, and ventricular hypertrophy, tachyarrhythmias, post myocardial ventricular dilation, insulin resistance, advancing chronic renal disease, and polycystic ovary syndrome.

\section{CONCLUSIONS}

Denervation (ablation) of sympathetic fibres in renal arteries was a safe procedure in this cohort of patients. Selective renal nerve ablation with RF energy via the renal artery using the Ardian system (Medtronic) led to significant and sustained decreases in mean values of arterial systolic and diastolic BP and pulse pressure in a six month follow up in patients with resistant hypertension with optimal pharmacotherapy compared to baseline measurements. In the absence of successful pharmacotherapy in this population, the procedure now adds benefit to their care. Certainly long term vascular and renal safety data will be required. The application of this therapy to patients whose BP has not proved resistant to life-long polypharmacy, or additional disease states such as heart failure, insulin resistance or type 2 diabetes, post myocardial ventricular dilation, tachycardia arrhythmias such as atrial fibrillation, and polycystic ovary syndrome, will require further investigation.

Conflict of interest: Paul A. Sobotka was medical director of Ardian Inc. and was consultant for Medtronic Inc. No other conflicts are present. 


\section{References}

1. Lloyd-Jones D, Adams RJ, Brown TM et al. Heart disease and stroke statistics: 2010 update: a report from the American Heart Association. Circulation, 2010; 121: e46-e215.

2. Wolf-Maier K, Cooper RS, Kramer H et al. Hypertension treatment and control in five European countries, Canada, and the United States. Hypertension, 2004; 43: 10-17.

3. Hoobler SW, Manning JT, Paine WG et al. The effects of splanchnicectomy on the blood pressure in hypertension;a controlled study. Circulation, 1951; 4: 173-183.

4. Krum H, Schlaich M, Whitbourn R et al. Catheter-based renal sympathetic denervation for resistant hypertension: a multicentre safety and proof-of-principle cohort study. Lancet, 2009; 373: 1275-1281.

5. Schlaich M, Krum H, Walton T et al. Two-year durability of blood pressure reduction with catheter-based renal sympathetic denervation. J Hypertens, 2010; 28 (suppl. A): e446.

6. Symplicity HTN-1 Investigators. Catheter-based renal sympathetic denervation for resistant hypertension: durability of blood pressure reduction out to 24 months. Hypertension, 2011; 57: 911-917.

7. Mahfoud F, Himmel F, Ukena C et al. Treatment strategies for resistant arterial hypertension. Dtsch Arztebl Int, 2011; 108: 725-731.

8. Krum H, Schlaich M, Whitbourn R et al. Catheter-based renal sympathetic denervation for resistant hypertension: a multicentre safety and proof-of-principle cohort study. Lancet, 2009; 373: 1275-1281

9. Collins R, Peto R, MacMahon S et al. Blood pressure, stroke, and coronary heart disease. Part 2, short-term reductions in blood pressure: overview of randomised drug trials in their epidemiological context. Lancet, 1990; 335: 827-839.
10. Blood Pressure Lowering Treatment Trialists' Collaboration. Effects of different blood-pressure-lowering regimens on major cardiovascular events: results of prospectively-designed overviews of randomised trials. Lancet, 2003; 362: 1527-1535.

11. Staessen JA, Wang JG, Thijs L. Cardiovascular prevention and blood pressure reduction: a quantitative overview updated until 1 March 2003. J. Hypertens, 2003; 21: 1055-1076.

12. Blood Pressure Lowering Treatment Trialists' Collaboration. Effects of different blood pressure-lowering regimens on major cardiovascular events in individuals with and without diabetes mellitus. Results of prospectively designed overviews of randomized trials. Arch Intern Med, 2005; 165: 1410-1419.

13. Gewirtz JR, Bisognano JD. Catheter-based renal sympathetic denervation: a targeted approach to resistant hypertension. Cardiol J, 2011; 18: 97-102.

14. Nomura G, Kurosaki M, Takabatake T et al. Reinnervation and renin release after unilateral renal denervation in the dog. J Appl Physiol, 1972; 33: 649-655.

15. Witkowski A, Prejbisz A, Florczak E et al. Effects of renal sympathetic denervation on blood pressure, sleep apnea course, and glycemic control in patients with resistant hypertension and sleep apnea. Hypertension, 2011; 58: 559-565.

16. Schlaich MP, Straznicky N, Grima M et al. Renal denervation: a potential new treatment modality for polycystic ovary syndrome? J Hypertens, 2011; 29: 991-996.

17. Mahfoud F, Schlaich M, Kindermann I et al. Effect of renal sympathetic denervation on glucose metabolism in patients with resistant hypertension: a pilot study. Circulation, 2011; 123: 1940-1946.

18. Schlaich MP, Hering D, Sobotka $P$ et al. Effects of renal denervation on sympathetic activation, blood pressure, and glucose metabolism in patients with resistant hypertension. Front Physiol, 2012; 3: 10. 


\title{
Denerwacja (ablacja) zakończeń nerwowych w tętnicach nerkowych: wczesne wyniki interwencyjnego leczenia nadciśnienia tętniczego
}

\author{
Krzysztof Bartuś ${ }^{1}$, Jerzy Sadowski ${ }^{1}$, Bogusław Kapelak ${ }^{1}$, Wojciech Zajdel ${ }^{2}$, Jacek Godlewski ${ }^{2}$, \\ Stanisław Bartuśs ${ }^{3}$, Maciej Bochenek ${ }^{1}$, Magdalena Bartuśs ${ }^{4}$, Krzysztof Żmudka ${ }^{2}$, Paul. A. Sobotka ${ }^{5}$ \\ 1Klinika Chirurgii Serca, Naczyń i Transplantologii, Szpital im. Jana Pawła II, Kraków \\ ${ }^{2}$ Szpital im. Jana Pawła II, Kraków \\ ${ }^{3}$ Szpital Uniwersytecki w Krakowie, Kraków \\ ${ }^{4}$ Katedra Farmakologii, Zakład Farmakologii Doświadczalnej, Kraków \\ ${ }^{5}$ The Ohio State University, Columbus, OH, USA; Medtronic Inc., Santa Rosa, CA, USA
}

\section{Streszczenie}

Wstęp: Nadciśnienie tętnicze jest jednym z najważniejszych czynników ryzyka rozwoju chorób układu sercowo-naczyniowego i zgonu.

Cel: Celem pracy była ocena zmian ciśnienia tętniczego u pacjentów poddanych procedurze ablacji zakończeń nerwowych w okolicy tętnic nerkowych (denerwacji) oraz ocena bezpieczeństwa wykonania procedury w czasie 6-miesięcznej kontroli pooperacyjnej.

Metody: Do procedury ablacji zakończeń nerwowych w okolicy tętnic nerkowych zakwalifikowano 28 pacjentów w wieku 42-72 lat (śr. 52,02 roku) ze zdiagnozowanym nadciśnieniem tętniczym, opornym na leczenie zachowawcze. Do wykonania angiografii tętnic nerkowych i procedury ablacji użyto cewnika SIMPLICITY firmy Ardian (obecnie Medtronic Inc. USA).

Wyniki: Średnie ciśnienie tętnicze przed procedurą, po 1, 3 i 6 miesiącach po procedurze wynosiły odpowiednio [mm Hg]: skurczowe: 176,6; 162,3 ( $p=0,004) ; 150,6$ ( $<<0,001) ; 147,2(p<0,001)$; rozkurczowe: 100,2; 90,3 ( $p<0,001)$; 91,79 ( $p=0,03) ; 88,5$ ( $p<0,001)$; ciśnienie tętna: 76,57; 75,18 ( $p=N S) ; 65,80$ ( $p<0,001) ; 62,15$ ( $p<0,001)$. Nie odnotowano istotnych powikłań po wykonaniu procedury i w czasie 6-miesięcznej kontroli pooperacyjnej.

Wnioski: W niniejszej pracy ablacja splotów nerwowych tętnic nerkowych nie wiązała się z wystąpieniem powikłań naczyniowych i nerkowych do 6. miesiąca od procedury. Ablacja nerwów okolicy tętnic nerkowych prowadzi do istotnego spadku skurczowego i rozkurczowego ciśnienia tętniczego i ciśnienia tętna. Polskie doświadczenie nie różni się znacząco od wyników dotyczących pozostałej grupy chorych, uzyskanych w międzynarodowych badaniach Symplicity I and Symplicity II. Długotrwała kontrola kliniczna jest konieczna w celu oceny trwałości leczenia i wystąpienia ewentualnych powikłań odległych.

Słowa kluczowe: nadciśnienie tętnicze, nadciśnienie nerkopochodne, nadciśnienie lekooporne, ablacja tętnic nerkowych

Kardiol Pol 2013; 71, 2: 152-158

\section{Adres do korespondencji:}

dr hab. n. med. Krzysztof Bartuś, Klinika Chirurgii Serca, Naczyń i Transplantologii, Uniwersytet Jagielloński, Szpital im. Jana Pawła II, ul. Prądnicka 80,

31-202 Kraków, tel: +48 1261430 75, faks: +48 1242339 00, e-mail:cool_chris@interia.pl

Praca wpłynęła: 02.05.2012 r.

Zaakceptowana do druku: 07.11.2012 r 